\title{
Estimation of Combining Ability and Gene Action in Some Egyptian Wheat Landraces
}

\author{
M.H. El- Shal, E.M. Habib and S. A. Arab \\ National Gene Bank, Agricultural Research Center, Giza, Egypt.
}

\begin{abstract}
CIVE LANDRACES from wheat (Triticum aestivum L.) collected from diverse areas of Egypt and their ten possible crosses as well used to establish the experimental materials for this investigation. We desire to assess the variations among wheat genotypes and available crosses to estimate the magnitude of general combining ability (GCA) and specific combining ability (SCA) for physiological traits, yield and yield components. Mean squares for parent showed high significant for net photosynthesis rate $(\mathrm{Pn})$, transpiration rate $(\mathrm{E})$, stomatal conductance $(\mathrm{C})$, days to maturity, no. of kernels per spike and 1000- kernel weight. Crosses mean squares showed high significant for Pn, E, C, no. of kernels per spike and 1000-kernel weight, on the other hand there was no significant for no. of spikes per plant and grain yield. High significant recorded for Parent vs crosses mean squares for E, C, no. of kernels per spike and 1000- kernel weight. The parental lines $\mathrm{L}_{1}$ exhibited significant positive desirable GCA effects for Pn, C and grain yield/plant. The most desirable SCA effects recorded by cross namely $\mathrm{L}_{1} \times \mathrm{L}_{3}$ for $\mathrm{C}$, days to maturity, no. of spikes per plant and grain yield/plant, also, $\mathrm{L}_{1} \times \mathrm{L}_{4}$ for $\mathrm{E}$, no. of kernels per spike and grain yield/plant. Although that there was a positive and negative correlation among traits study but was not significant value except the correlation between transpiration rate $(\mathrm{E})$ moreover, stomatal conductance $(\mathrm{C})$ was positive significant value. $(\mathrm{r}=0.90)$.
\end{abstract}

Keywords: General combining ability (GCA), Specific combining ability (SCA), Net photosynthesis rate (Pn), Transpiration rate (E), Stomatal conductance(C).

Bread wheat (Triticum aestivum L.) is the major staple food source for a large part of world population. Any breeding program aiming at hybridization, knowledge of better combiner parents is a prerequisite. It is important to achieve genetic gain within limited resources and minimum time. Combining ability in a complete diallel cross of wheat varieties studied by Chowdhry \& Ahmad (1990). A high net photosynthesis rate had considered one of the most important breeding strategies for better adaptation to stressful environments (Austin, 1980 and 1989). The photosynthetic activity of flag leaves is especially important during grain filling when the older leaves begin senescing (Loss \& Siddique 1994 and Turner, 1997). The main objectives of the present investigation are to evaluate the variations among wheat genotypes and available crosses, to estimate the magnitude of general combining ability (GCA) and specific combining ability (SCA) to improve wheat. 
In cereals, most of the carbohydrate in the grain comes from photosynthesis after the ears emerge. Photosynthesis in the flag leaf provides the major part of the carbohydrate of the grain (Lupton, 1969; Thorne, 1963, 1965; Puckridge, 1968 and Stoy, 1963). Consequently, the cereal ideotype should possess maximum and efficient rates of photosynthesis of the flag leaf. Ejaz \& Ahmad (2010) because in some studies a positive correlation has been found between rate of photosynthesis and ultimate yield. Photosynthesis is one of the major physiological phenomena contributing to growth and grain yield, it had presumed that rate of photosynthesis of the flag leaf from anthesis to grain filling may contribute largely to grain development and hence ultimate yield as compared to the other leaves of a plant.

The main objectives of the present investigation are to assess the variations among wheat genotypes and available crosses to estimate the magnitude of general combining ability (GCA) and specific combining ability (SCA) for physiological traits, yield and yield components.

\section{Plant materials}

\section{Materials and Methods}

Five landraces collected from diverse areas of Egypt as well used to establish the experimental materials for this investigation. The names and origins of these varieties and Landraces presented in Table 1.

TABLE 1. Name, pedigree and source of the studied bread wheat genotypes.

\begin{tabular}{|l|c|l|c|}
\hline No. & Genotypes & Pedigree & Source \\
\hline 1 & L 1 & Landraces & New valley \\
\hline 2 & L 2 & Landraces & Sohag \\
\hline 3 & L 3 & Landraces & Sohag \\
\hline 4 & L 4 & Landraces & Sohag \\
\hline 5 & L 5 & Landraces & Qena \\
\hline
\end{tabular}

In 2012/2013, five genotypes from wheat (Triticum aestivum L.) as well as ten crosses as result cross combinations among of theses genotypes evaluated in Gemmeiza Agricultural Research Station to estimate combining ability and gene action for physiological traits and yield components.

The experiment included the five parents and their ten possible crosses in a randomized complete block design (RCBD) with three replications. The planting date was on $24^{\text {th }}$ of November. The experiment normally irrigated by giving the recommended number (5) of irrigations. Each plot consisted of one row, of 1.5 meters long and $30 \mathrm{~cm}$ wide. Grains individually sown in hills at $20 \mathrm{~cm}$ space between plants within row. Data were recovered from each plot for physiological Egypt. J. Agron. 36, No. 2 (2014) 
traits; net photosynthesis rate $(\mathrm{Pn})\left(\mu \mathrm{mol} / \mathrm{m}^{2} / \mathrm{s}\right)$, transpiration $\operatorname{rate}(\mathrm{E})$ $\left(\mathrm{milimol} / \mathrm{m}^{2} / \mathrm{s}\right)$ and stomatal conductance $(\mathrm{C})\left(\mathrm{milimol} / \mathrm{m}^{2} / \mathrm{s}\right)$, all data for physiological measurements have been taken by the CI-340 Ultra-Light Portable Photosynthesis System and for yield and yield components were recorded for each plot; days to maturity, no. of spikes per plant, no. of kernels per spike, 1000- kernel weight and grain yield-plant.

The data obtained for each trait from each replicate were analyzed on the mean of the ten individual plants chosen randomly. General and specific combining ability estimates were obtained by employing Griffing (1956) diallel cross analysis designated as method 2 model 1.

Monthly average temperature and amount of rainfall and mechanical and chemical analysis of experimental soil are shown in Tables 2 and 3.

TABLE 2. Meteorological data at Al- Gemmeiza location during 2012/2013 growing season.

\begin{tabular}{|c|c|c|c|c|}
\hline Month no. & $\begin{array}{c}\text { Means of air } \\
\text { temperature } \\
\left({ }^{\circ} \mathrm{C}\right)\end{array}$ & $\begin{array}{c}\text { Max relative } \\
\text { humidity } \\
(\%)\end{array}$ & $\begin{array}{c}\text { Min relative } \\
\text { humidity } \\
(\%)\end{array}$ & Rainfall rate \\
\hline Nov.2012 & 17.62 & 9.66 & 25.28 & \multirow{7}{*}{$20 \mathrm{~mm}$} \\
\hline Dec.2012 & 13.18 & 9.18 & 19.64 & \\
\hline Jan.2013 & 10.63 & 4.04 & 19.03 & \\
\hline Feb.2013 & 12.68 & 6.13 & 18.69 & \\
\hline Mar.2013 & 20.74 & 11.96 & 32.91 & \\
\hline April.2013 & 18.09 & 8.43 & 29.01 & \\
\hline May 2013 & 20.81 & 13.60 & 28.32 & \\
\hline
\end{tabular}

TABLE 3. Mechanical and chemical analysis of experimental soil in 2012/ 2013 seasons at Gemmeiza Agricultural Research Station.

\begin{tabular}{|l|c|}
\hline \multicolumn{2}{|c|}{ Mechanical analysis } \\
\hline Clay \% & 45.48 \\
\hline Silt \% & 29.35 \\
\hline Sand \% & 24.4 \\
\hline Organic mater & 0.5 \\
\hline Textural class & Clay \\
\hline \multicolumn{2}{|c|}{ Chemical analysis } \\
\hline Available N PPM & 30.4 \\
\hline Available P PPM & 5.86 \\
\hline Available K PPM & 400 \\
\hline
\end{tabular}


Analysis of variance

\section{Results and Discussion}

Estimates of combining abilities were obtained by employing Griffing's diallel cross analysis (1956) designated as method 2 model I. Mean squares for genotypes recorded a high significant for all treatments except No. of spikes per plant gave no significant indicated that overall difference among genotypes (Table 4 and 4 Cont.).

TABLE 4. Mean square estimates of ordinary analysis and combining ability analysis for all.

\begin{tabular}{|l|c|c|c|c|c|}
\hline \multicolumn{1}{|c|}{ S.O.V. } & d.f. & $\begin{array}{c}\text { Net } \\
\text { photosynthesis } \\
\text { rate (Pn) }\end{array}$ & $\begin{array}{c}\text { Transpiration } \\
\text { rate (E) }\end{array}$ & $\begin{array}{c}\text { Stomatal } \\
\text { conductance } \\
(\mathbf{C})\end{array}$ & $\begin{array}{c}\text { Days to } \\
\text { maturity }\end{array}$ \\
\hline Rep/L & 2 & $33.644^{*}$ & $0.318^{*}$ & $4021.442^{* *}$ & 5.089 \\
\hline Genotypes & 14 & $153.037^{* *}$ & $2.074^{* *}$ & $16708.777^{* *}$ & $6.517 * *$ \\
\hline Parent & 4 & $346.038^{* *}$ & $5.235^{* *}$ & $33541.231^{* *}$ & $14.067 * *$ \\
\hline Cross & 9 & $84.226 * *$ & $0.866^{* *}$ & $9446.244 * *$ & 3.856 \\
\hline Par.vs.cr. & 1 & 0.335 & $0.303^{*}$ & $14741.760 * *$ & 0.278 \\
\hline Error & 28 & 8.774 & 0.061 & 181.757 & 1.779 \\
\hline GCA & 4 & $111.747 * *$ & $1.692 * *$ & $11529.453 * *$ & $2.829 *$ \\
\hline SCA & 10 & $26.719 * *$ & $0.291 * *$ & $3185.647 * *$ & 1.910 \\
\hline Error & 28 & 2.925 & 0.020 & 60.586 & 0.593 \\
\hline GCA /SCA & - & 4.182 & 8.814 & 3.619 & 1.481 \\
\hline
\end{tabular}

$*$ and $* *$ significant at 0.05 and 0.01 levels of probability, respectively.

Mean squares for parent showed high significant for net photosynthesis rate $(\mathrm{Pn})$, transpiration rate (E), stomatal conductance (C), days to maturity, no. of kernels per spike and 1000- kernel weight but it gave no significant for no. of spikes per plant and grain yield plant indicating that wide diversity between the parental used in the present study for these traits.

Crosses mean squares showed high significant for net photosynthesis rate $(\mathrm{Pn})$, transpiration rate $(\mathrm{E})$, stomatal conductance $(\mathrm{C})$, no. of kernels per spike and 1000-kernel weight, on the other hand, there was no significant for no. of spikes per plant and grain yield. On the other hand, there were no significant for days to maturity and no. of spikes per plant.

Parent vs crosses mean squares for transpiration rate, stomatal conductance, no. of kernels per spike and 1000- kernel weight gave high significant meanwhile, net photosynthesis rate, days to maturity, no. of spikes per plant and grain yield plant showed no significant. 
TABLE 4. Cont.

\begin{tabular}{|l|l|c|c|c|c|}
\hline \multicolumn{1}{|c|}{ S.O.V. } & d.f. & $\begin{array}{c}\text { No. of } \\
\text { spikes per } \\
\text { plant }\end{array}$ & $\begin{array}{c}\text { No. of } \\
\text { kernels per } \\
\text { spike }\end{array}$ & $\begin{array}{c}\text { 1000- kernel } \\
\text { weight }\end{array}$ & $\begin{array}{c}\text { Grain yield- } \\
\text { plant }\end{array}$ \\
\hline Rep/L & 2 & 0.163 & 20.042 & 4.197 & 0.928 \\
\hline Genotypes & 14 & 1.155 & $48.542^{* *}$ & $71.557^{* *}$ & $6.208^{*}$ \\
\hline Parent & 4 & 0.091 & $51.609^{* *}$ & $163.758^{* *}$ & 3.801 \\
\hline Cross & 9 & 1.618 & $44.631^{* *}$ & $24.308^{* *}$ & $7.345^{* *}$ \\
\hline Par.vs.cr. & 1 & 1.248 & $71.467^{*}$ & $127.997^{* *}$ & 5.605 \\
\hline Error & 28 & 0.948 & 10.233 & 5.919 & 1.821 \\
\hline GCA & 4 & 0.091 & 5.438 & $54.489^{* *}$ & $1.811^{*}$ \\
\hline SCA & 10 & 0.503 & $20.478^{* *}$ & $11.597^{* *}$ & $2.173^{* *}$ \\
\hline Error & 28 & 0.316 & 3.411 & 1.973 & 0.607 \\
\hline GCA /SCA & - & 0.181 & 0.266 & 4.699 & 0.833 \\
\hline
\end{tabular}

* and ** significant at 0.05 and 0.01 levels of probability, respectively.

After obtaining significant differences among genotype for various traits, combining ability analysis had done to perceive superior progeny when one parent combined with another parent. General combining ability (GCA) provided an estimation of degree of additive gene action and specific combining ability (SCA) exhibited the performance of two particular varieties/lines in a specific cross, which would reflect non-additive type of gene action (Phoelman \& Sleper, 1997).

\section{Mean performances}

The mean performance of the 5 parents and 10 hybrids of wheat presented in Table 5 and 5 Cont.

The results in Table (5) clearly show that the highest mean values of (Pn) for parental was L1 followed by L4 at trait studied. Meanwhile, the lowest values obtained by L5 followed by L2 and L3. In addition, crosses L2 x L3, L2 x L5 and L1 x L3 recorded the greatest values.

Regarding E, the lowest values for parental lines obtained by L2 followed by L1. Meanwhile, highest mean values for parental L5 followed by L3 and L4 at trait studied. In addition, crosses L4 x L5 and L1 x L5 recorded the lowest values. 
TABLE 5. The genotypes mean performance for all traits studied .

\begin{tabular}{|l|c|c|c|c|}
\hline Genotypes & (Pn) & (E) & (C) & $\begin{array}{c}\text { Days to } \\
\text { maturity }\end{array}$ \\
\hline L 1 & 31.357 & 4.203 & 256.693 & 139.000 \\
\hline L 2 & 14.803 & 4.477 & 331.413 & 136.333 \\
\hline L 3 & 14.653 & 3.993 & 191.007 & 139.667 \\
\hline L 4 & 15.227 & 3.813 & 176.043 & 141.000 \\
\hline L 5 & 1.053 & 1.220 & 46.430 & 136.000 \\
\hline L 1x L 2 & 14.610 & 3.540 & 225.970 & 137.667 \\
\hline L 1x L 3 & 17.500 & 4.370 & 265.270 & 136.000 \\
\hline L 1x L 4 & 18.180 & 3.080 & 131.710 & 139.000 \\
\hline L 1x L 5 & 12.027 & 2.740 & 161.507 & 138.000 \\
\hline L 2x L 3 & 25.047 & 3.513 & 146.873 & 139.333 \\
\hline L 2x L 4 & 15.570 & 3.110 & 90.053 & 139.000 \\
\hline L 2x L 5 & 17.923 & 3.473 & 188.467 & 139.000 \\
\hline L 3x L 4 & 13.720 & 3.710 & 174.387 & 138.333 \\
\hline L 3x L 5 & 13.460 & 3.657 & 152.447 & 139.333 \\
\hline L 4x L5 & 4.320 & 2.480 & 82.540 & 140.000 \\
\hline L.S.D 5\% & 4.952 & 0.414 & 22.544 & 2.230 \\
\hline L.S.D 1\% & 6.681 & 0.558 & 30.415 & 3.009 \\
\hline L & & & & \\
\hline
\end{tabular}

Net photosynthesis rate $(\mathrm{Pn})$, transpiration rate (E), stomatal conductance(C), days to maturity, no. of spikes per plant, no. of kernels per spike, 1000- kernel weight and grain yield-plant.

\section{TABLE 5. Cont.}

\begin{tabular}{|l|c|c|c|c|}
\hline Genotypes & $\begin{array}{c}\text { No. of spikes per } \\
\text { plant }\end{array}$ & $\begin{array}{c}\text { No. of kernels } \\
\text { per spike }\end{array}$ & $\begin{array}{c}\text { 1000- kernel } \\
\text { weight }\end{array}$ & $\begin{array}{c}\text { Grain yield- } \\
\text { plant }\end{array}$ \\
\hline L 1 & 14.800 & 53.067 & 30.107 & 29.297 \\
\hline L 2 & 14.667 & 53.933 & 45.977 & 26.867 \\
\hline L 3 & 15.067 & 56.867 & 43.840 & 28.993 \\
\hline L 4 & 15.067 & 46.400 & 31.570 & 26.960 \\
\hline L 5 & 14.867 & 56.133 & 33.260 & 28.247 \\
\hline L 1x L 2 & 14.400 & 58.867 & 41.387 & 27.993 \\
\hline L 1x L 3 & 16.400 & 52.467 & 39.200 & 31.160 \\
\hline L 1x L 4 & 16.200 & 61.600 & 37.330 & 30.780 \\
\hline L 1x L 5 & 15.000 & 52.000 & 38.290 & 28.500 \\
\hline L 2x L 3 & 14.733 & 52.200 & 40.787 & 26.993 \\
\hline L 2x L 4 & 15.133 & 51.067 & 44.140 & 28.753 \\
\hline L 2x L 5 & 15.867 & 60.667 & 45.633 & 30.147 \\
\hline L 3x L 4 & 14.200 & 58.000 & 37.123 & 26.647 \\
\hline L 3x L 5 & 15.467 & 55.600 & 42.173 & 27.613 \\
\hline L 4x L5 & 15.067 & 57.067 & 39.220 & 29.627 \\
\hline L.S.D 5\% & 1.628 & 5.349 & 4.067 & 29.297 \\
\hline L.S.D 1\% & 2.197 & 7.217 & 5.487 & 26.867 \\
\hline & & & & \\
\hline
\end{tabular}

Egypt. J. Agron. 36, No. 2 (2014) 
The highest mean values of $\mathrm{C}$ were recorded with parents $\mathrm{L} 2$ followed by L1. Meanwhile, the lowest values recorded with $\mathrm{L}_{5}$ followed by $\mathrm{L} 4$ and L3. In addition, the highest values obtained from crosses L1 x L3 followed by L1 x L2, meanwhile, the lowest SC obtained with L4 x L5 and L2 x L4. Stomatal closure increases the resistance to $\mathrm{CO}_{2}$ diffusion into the leaf.

An inhabitation of chloroplast activity low leaf temperature decreases the capacity to fix $\mathrm{CO}_{2}$. The stomatal conductance might play an important role in the high Pn (Johson et al., 1984 and Inoue et al., 2004).

Shimshi \& Ephart (1975), who worked with up to 11 cultivars of spring wheat grown under field conditions, suggested that the promoter method would be useful in wheat breeding programs. The study showed that SC was the best method to use screen plants for drought resistance.

As days to maturity, the parental lines L5 and L2 gave the lowest mean value followed by the parental line L1 and L3. In addition, the parental combination that incorporated earliness of those $F_{1}$ hybrids was L1 $x$ L3 and L1 x L2. Earliness if it had found in wheat is favorable for escaping from disease as well as high temperature in maturity and stress conditions, which have the same effect.

Both of parental lines L3 and L4 recorded the highest number of spikes per plant. In addition, the cross L1 x L3 recorded the highest followed by L1 x L4. The parental line L3 obtained the greatest value number of kernels per spike followed by L4. In addition, L1 x L4 and L $2 \times$ L5 recorded the greatest value in trait studied.

Regarding the parental line L2 obtained the greatest value of 1000- kernel weight followed by L3. In addition, L $2 \times$ L4 and L2 x L5 recorded the greatest value in trait studied. Both of parental lines L1 and L3 recorded the highest grain yield-plant. In addition, three crosses L1 x L3; L2 x L5and L1 x L4 recorded the highest of this trait.

\section{Combining ability}

General combining ability

Estimates of the general combining ability effects (GCA) for individual parental line in each trial are given in Table 6 and 6Cont. General combining ability effects computed herein were found to differ significantly from zero in all cases. High positive values would be interest under all traits in question except transpiration rate and days to maturity where high negative effect would be useful from the breeder point of view.

Regarding days to maturity, no. of spikes per plant and no. of kernels per spike there was no GCA significant effects for the three traits except, one positive as for net photosynthesis rate, the parental lines L1 gave the highest significant positive GCA effects followed by line L2. Meanwhile, the parental 
line L5 was the one of the highest significant negative GCA for transpiration rate effects. As for stomatal conductance three parental lines out of five parents; L2, L1 and L3 gives the highest significant positive GCA effects. Those parents had considered as the best combiners for this trait.

TABLE 6. Estimates of general combining effects for parents evaluated.

\begin{tabular}{|cc|c|c|c|c|}
\hline \multicolumn{2}{|c|}{ Parents } & $\begin{array}{c}\text { Net photosynthesis } \\
\text { rate (Pn) }\end{array}$ & $\begin{array}{c}\text { Transpiration } \\
\text { rate (E) }\end{array}$ & $\begin{array}{c}\text { Stomatal } \\
\text { conductance } \\
(\mathbf{C})\end{array}$ & $\begin{array}{c}\text { Days to } \\
\text { maturity }\end{array}$ \\
\hline L 1 & & $4.75^{* *}$ & $0.23^{* *}$ & $35.65^{* *}$ & -0.34 \\
L 2 & $1.57^{* *}$ & $0.29^{* *}$ & $37.98^{* *}$ & -0.49 \\
L3 & 1.04 & $0.38^{* *}$ & $10.38^{* *}$ & 0.18 \\
L 4 & & $-1.36^{*}$ & -0.08 & $-31.08^{* *}$ & $1.04^{* *}$ \\
L 5 & $-5.99^{* *}$ & $-0.82^{* *}$ & $-52.93^{* *}$ & -0.39 \\
\hline L.S.D g gi & 0.05 & 1.18 & 0.10 & 5.39 & 0.53 \\
& 0.01 & 1.60 & 0.13 & 7.26 & 0.72 \\
\hline L.S.D & 0.05 & 1.87 & 0.16 & 8.53 & 0.84 \\
gi - $\hat{g} j$ & 0.01 & 2.52 & 0.21 & 11.48 & 1.14 \\
\hline
\end{tabular}

* and ** significant at 0.05 and 0.01 levels of probability, respectively.

TABLE 6. Cont .

\begin{tabular}{|c|c|c|c|c|c|}
\hline \multicolumn{2}{|c|}{ Parents } & $\begin{array}{c}\text { No. of spikes } \\
\text { per plant }\end{array}$ & $\begin{array}{c}\text { No. of kernels } \\
\text { per spike }\end{array}$ & $\begin{array}{c}\text { 1000- kernel } \\
\text { weight }\end{array}$ & $\begin{array}{c}\text { Grain } \\
\text { yield-plant }\end{array}$ \\
\hline \multicolumn{2}{|l|}{ L 1} & 0.12 & 0.10 & $-2.80 * *$ & $0.80 * *$ \\
\hline \multicolumn{2}{|l|}{ L 2} & -0.19 & 0.04 & $3.98 * *$ & $-0.54 *$ \\
\hline \multicolumn{2}{|l|}{ L3 } & 0.02 & 0.23 & $1.56^{* *}$ & -0.15 \\
\hline \multicolumn{2}{|l|}{ L 4} & -0.01 & $-1.41 *$ & $-2.15^{* *}$ & -0.24 \\
\hline \multicolumn{2}{|l|}{ L 5} & 0.05 & 1.03 & -0.60 & 0.14 \\
\hline L.S.D ĝi & $\begin{array}{l}0.05 \\
0.01\end{array}$ & $\begin{array}{l}0.39 \\
0.52\end{array}$ & $\begin{array}{l}0.97 \\
1.31\end{array}$ & $\begin{array}{l}0.54 \\
0.73\end{array}$ & $\begin{array}{l}1.28 \\
1.72\end{array}$ \\
\hline $\begin{array}{l}\text { L.S.D } \\
\hat{\mathrm{g} i}-\hat{\mathrm{g} j}\end{array}$ & $\begin{array}{l}0.05 \\
0.01\end{array}$ & $\begin{array}{l}0.62 \\
0.83\end{array}$ & $\begin{array}{l}1.54 \\
2.07\end{array}$ & $\begin{array}{l}0.85 \\
1.15\end{array}$ & $\begin{array}{l}2.02 \\
2.72\end{array}$ \\
\hline
\end{tabular}

Significant GCA effects for days to maturity and another negative significant GCA effects no. of kernels per spike for the parental line L4.

For 1000- kernel weight the parental line L2, exhibited significant positive desirable GCA effects followed by the parental line L3. Therefore, both of two lines, could be considered as an excellent parents in breeding programs towards releasing cultivars by this trait for increasing grain yield /plant.

Egypt. J. Agron. 36, No. 2 (2014) 
As for grain yield per plant, the parental lines L1 exhibited significant positive desirable GCA effects. Therefore, this parent could considered as the best combiner for this trait and some of its components.

Specific combining ability

Specific combining ability effects " $\mathrm{s}_{\mathrm{ij}}$ " of the parental combinations had computed for all the studied measurements in Table 7 and 7 Cont.

The most desirable "s $\mathrm{s}_{\mathrm{ij}}$ " effects were recorded by crosses $\mathrm{L}_{2} \times \mathrm{L}_{3}$ and $\mathrm{L}_{2} \mathrm{x} \mathrm{L}_{5}$ under trait studied for Pn; one, three, five and six crosses, for transpiration rate; two, four, seven, eight and nine crosses for stomatal conductance; two, eight and nine, for days to maturity crosses expressed significant desirable " $\mathrm{s}_{\mathrm{ij}}$ " traits studied, respectively.

TABLE 7. Estimates of specific combining ability effects for the ten crosses studied.

\begin{tabular}{|c|c|c|c|c|}
\hline Genotypes & $\begin{array}{c}\text { Net photosynthesis } \\
\text { rate }(\mathbf{P n})\end{array}$ & $\begin{array}{l}\text { Transpiration } \\
\text { rate }(\mathrm{E})\end{array}$ & $\begin{array}{c}\text { Stomatal } \\
\text { conductance } \\
(\mathrm{C})\end{array}$ & $\begin{array}{l}\text { Days to } \\
\text { maturity }\end{array}$ \\
\hline L 1x L 2 & $-6.94 * *$ & $-0.35 * *$ & -9.58 & -0.07 \\
\hline L 1x L 3 & $-3.52 *$ & $0.39 * *$ & $57.32 * *$ & $-2.41^{* *}$ \\
\hline $\mathrm{L} 1 \mathrm{x}$ L 4 & -0.44 & $-0.44 * *$ & $-34.78 * *$ & -0.26 \\
\hline L $1 x$ L 5 & -1.97 & -0.03 & $16.87 *$ & 0.17 \\
\hline L 2x L 3 & $7.21 * *$ & $-0.53^{* *}$ & $-63.41 * *$ & 1.07 \\
\hline L $2 x$ L 4 & 0.13 & $-0.47 * *$ & $-78.77 * *$ & -0.12 \\
\hline L 2x L 5 & $7.11 * *$ & $0.64 * *$ & $41.49 * *$ & 1.31 \\
\hline $\mathrm{L} 3 x \mathrm{~L} 4$ & -1.19 & 0.04 & $33.16^{* *}$ & $-1.45^{*}$ \\
\hline L $3 x$ L 5 & -1.19 & 0.04 & $33.16^{* *}$ & $-1.45^{*}$ \\
\hline $\mathrm{L} 4 \times \mathrm{L} 5$ & $-3.56^{*}$ & 0.01 & 4.63 & 0.79 \\
\hline $\begin{array}{c}\text { L.S.D (sij) } \\
5 \%\end{array}$ & 3.06 & 0.25 & 13.93 & 1.38 \\
\hline $\begin{array}{c}\text { L.S.D (sij) } \\
1 \%\end{array}$ & 4.12 & 0.34 & 18.75 & 1.86 \\
\hline
\end{tabular}

The most desirable " $s_{i j}$ " effects recorded by cross namely $L_{1} \times L_{3}$ for no. of spikes per plant, $\mathrm{L}_{1} \times \mathrm{L}_{4}$ and $\mathrm{L}_{2} \times \mathrm{L}_{5}$ for no. of kernels per spike. As for 1000kernel weight, there was no positive desirable " $s_{i j}$ " effects.

Regarding to grain yield/plant, two and three parental combinations expressed significant positive "Sij" effects under traits studied, respectively. The cross $\mathrm{L}_{1} \times \mathrm{L}_{3}$ under traits studied recorded the meantime, the most desirable "Sij" effects. 
TABLE 7. Cont.

\begin{tabular}{|c|c|c|c|c|}
\hline Genotypes & No. of spikes per plant & $\begin{array}{c}\text { No. of kernels } \\
\text { per spike }\end{array}$ & $\begin{array}{c}1000- \\
\text { kernel } \\
\text { weight }\end{array}$ & $\begin{array}{l}\text { Grain } \\
\text { yield- } \\
\text { plant }\end{array}$ \\
\hline L $1 x$ L 2 & -0.78 & 2.77 & -0.33 & -1.08 \\
\hline L $1 x$ L 3 & $1.01 *$ & $-3.82 *$ & -0.09 & $1.69 *$ \\
\hline L $1 \times$ L 4 & 0.84 & $6.95 * *$ & 1.75 & $1.40^{*}$ \\
\hline L $1 x$ L 5 & -0.42 & $-5.09 * *$ & 1.16 & -1.26 \\
\hline L 2x L 3 & -0.35 & $-4.03 *$ & $-5.29 * *$ & -1.14 \\
\hline L 2x L 4 & 0.08 & $-3.52 *$ & 1.78 & 0.72 \\
\hline L $2 x$ L 5 & 0.76 & $3.64 *$ & 1.72 & 1.73 \\
\hline L $3 x$ L 4 & $-1.06^{*}$ & 3.22 & $-2.82 *$ & $-1.78^{*}$ \\
\hline L 3x L 5 & $-1.06^{*}$ & 3.22 & $-2.82 *$ & $-1.78 *$ \\
\hline L 4x L 5 & -0.23 & 1.49 & 1.44 & 0.91 \\
\hline L.S.D (sij) 5\% & 1.01 & 3.30 & 2.51 & 1.39 \\
\hline L.S.D (sij) $1 \%$ & 1.35 & 4.45 & 3.38 & 1.88 \\
\hline
\end{tabular}

and ${ }^{* * *}$ significant at 0.05 and 0.01 levels of probability, respectively.

The conclusion of the results obtained here concerning general and specific combining ability effects could indicate that the excellent hybrid combinations obtained from the three possible combinations between the parents of high and low general combining ability effects, i.e. high $\times$ high, high $\times$ low and low $\times$ low. Consequently, it concluded that general combining ability effects of the parental lines were generally unrelated to the specific combining ability effects of their respective crosses. Similar conclusion was also drawn by Seleem (1993), Hewezi (1996) and Seleem \&Koumber (2011).

\section{Correlation coefficient}

The correlation coefficient among phenotypic correlation coefficients of yield, physioligical traits computed for five genotypes studied presented in Table 8 .

Although that there was a positive and negative correlation among traits study but was not significant value except the correlation between transpiration rate $(\mathrm{E})$ and stomatal conductance $(\mathrm{C})$ was positive significant value. $(r=0.90)$.

The conclusion of these results are showing that physiological characteristics are poorly correlated with yield and yield components this may be due to polygenic nature of yield efforts.

Egypt. J. Agron. 36, No. 2 (2014) 
TABLE 8. Phenotypic correlation coefficients of yield and physiological traits.

\begin{tabular}{|l|r|r|r|r|r|r|c|}
\hline & Pn & E & C & DM & NSP & NKS & 1000- KW \\
\hline E & 0.756 & & & & & & \\
\hline C & 0.669 & $0.90 *$ & & & & & \\
\hline DM & 0.471 & 0.464 & 0.063 & & & & \\
\hline NSP & -0.152 & -0.094 & -0.499 & 0.761 & & & \\
\hline NKS & -0.259 & -0.292 & -0.132 & -0.603 & -0.269 & & \\
\hline $1000-K W$ & -0.207 & 0.362 & 0.458 & -0.299 & -0.203 & 0.478 & \\
\hline GY & 0.357 & -0.102 & -0.205 & 0.111 & 0.154 & 0.557 & -0.228 \\
\hline
\end{tabular}

\section{Reference}

Austin, R.B. (1989) Maximizing crop production in water limited environments. In: "Drought Resistance in Cereals". F.W.G. Baker (Ed.) p.15-25. CAB International, Wallingford, England.

Austin, R.B., Bingham, J., Blackwell, R.D., Evans, R.T., Ford, M.A., Morgan, C.L. and Taylor, M. (1980) Genetic improvements in winter wheat yields since 1900 and associated physiological changes. J. Agric. Sci. 94, 675-689.

Chowdhry, M.A. and Ahmad, B. (1990) Combining ability in a seven-parent diallel cross of spring wheat. Pakistan J. Sci. Res. 42, 18-24.

Ejaz, A. W. and Ahmad, R. (2010) Physiological responses to water stress and nitrogen management in wheat (Triticum aestivum L.) evaluation of gas exchange, water relations and water use efficiency. Fourteenth Inter. Water Techn. Conf., IWTC 14, Egypt.

Griffings, J.B. (1956) Concept of general and specific combining ability in relation to diallel crosses system. Aust. J. Biol. Sci. 9, 463-493.

Hewezi, T. A. (1996) Graphical analysis of diallel cross of some bread wheat varieties. M.Sc. Thesis, Faculty of Agric. Minufiya Univ., Egypt.

Inoue, T., Inanaga, S., Sugimoto, Y. and Eneji, A.E. (2004) Effect of drought on ear and flag leaf photosynthesis of two wheat cultivars differing in drought resistance. Photosynthetica, 42 (4), 559-565.

Johnson, R. C., Nguyen, H. T. and Croy, L. I. (1984) Osmotic adjustment and solute accumulation in two wheat genotypes differing in drought resistance. Crop Sci. 24 (5), 957- 962.

Loss, S.P. and Siddique, K.H.M. (1994). Morphological and physiological traits associated with wheat yield increases in Mediterranean environments. Adv. Agron. 52, 229-276. 
Lupton, F.G.H. (1969) Estimation of yield in wheat from measurements of photosynthesis and translocation in the field. Ann. Appl. Biol. 64, 363-374.

Phoelman, J.M. and Sleper, D.A. (1997) "Breeding Field Crops". $4^{\text {th }}$ ed, pp. 259-61. Iowa State University Press.

Puckridge, D.W. (1968) Photosynthesis of wheat under field conditions. I. The interaction of photosynthetic organs. Aust. J. Agric. Res. 19, 711- 719.

Seleem, S.A. (1993) Heterosis and combining ability in common wheat. M.Sc. Thesis, Minufiya Univ., Egypt.

Seleem, S.A. and Koumber, R.M.A. (2011) Estimation of combining ability and gene action in the F1 and F2 generations in some breed wheat crosses. Minufiy J. Agric. Res. 36 (6), 1627-1648.

Shimishi, D. and Ephrat, J. E. (1975) Stomatal behavior of wheat cultivars in relation to their transpiration, photosynthesis and yield. Agron. J. 67, 326-330.

Stoy, V. (1963) The translocation of $\mathrm{C}^{14}$ labelled photosynthetic products from the leaf to the ear in wheat. Physiologia Plantarum, 16, 851- 866.

Thorne, G. N. (1963) Varietal differences in photosynthesis of ears and leaves of barley. Ann. Bot. 27, 155 -174.

Thorne, G. N. (1965) Photosynthesis of ears and flag leaves of wheat and barley. Ann. Bot. 29, 317- 329.

Turner, N.C. (1997) Further progress in crop water relationship. Adv. Agron. 58, 293-338. 


\section{تقدير كل من القدرة على الائتلاف والفعل الجيني في بعض الأقماح البلاية المصرية من القاية}

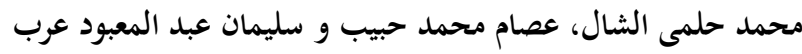

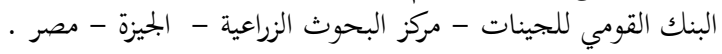

أجريت هذه التجربة على خمس سلالات من قمح الخبز والتي تم تجميعها من

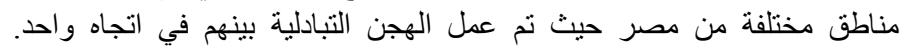

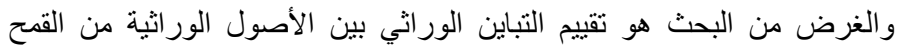

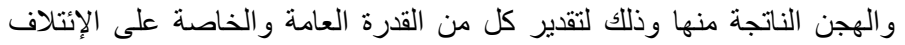

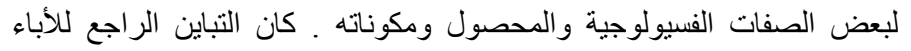

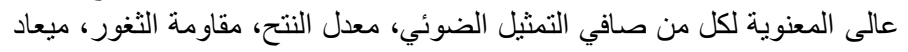

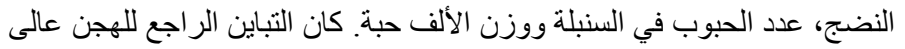

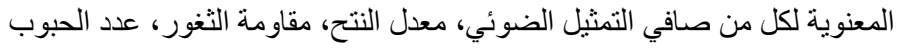

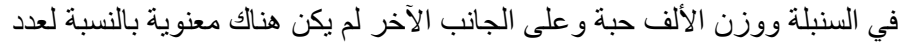

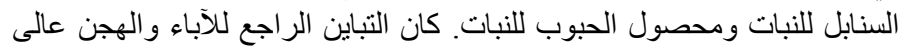

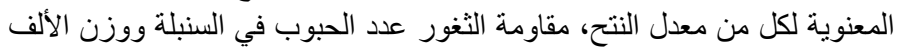
حبة. أظهرت السلالة L1 قدرة عامة علة على الائتلاف لكل من صناومة صافي التمثيل

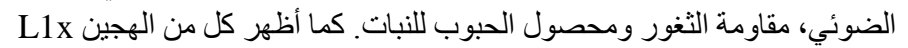

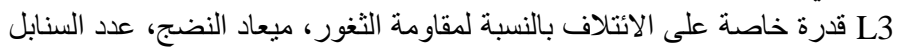

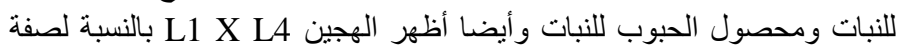

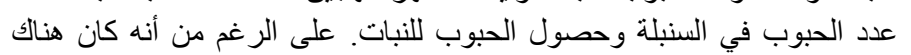

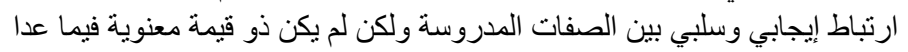
الإرتباط بين معدل النتح (E) ومقاومة الثغور (C) كان ذو قيمة لئمن معنوية إيجابية

$$
.(\cdot 69 \cdot=r)
$$

